\title{
PESQUISAS, PRÁTICAS DOCENTES E CONSIDERAÇÕES SOBRE A EDUCAÇÃO NA ATUALIDADE
}

A quarta edição da e-Mosaicos - Revista Multidisciplinar de Ensino, Pesquisa, Extensão e Cultura do Instituto de Aplicação Fernando Rodrigues da Silveira apresenta aos seus leitores a diversidade temática que a caracteriza.

A seção artigos é aberta com o texto de Bonnie Axer discutindo a política de leitura no município do Rio de Janeiro, considerando a concepção de currículo como enunciação cultural (MACEDO, 2007) e analisa dois documentos da Secretaria Municipal de Educação do Rio de Janeiro, um de 1996 e outro de 2010, e o viés da leitura e da formação de leitores. A preocupação com a formação de leitores também se faz presente no artigo de Denise Brasil e Adriana Freitas ao trazerem a discussão sobre o modernismo e o Ensino Médio, além de considerarem a construção de projetos que sejam permeados pela interdisciplinaridade. Seguindo pela vertente do campo do ensino, Cristina Bianchi, Marisa Silva, Yollanda Ferreira, Rachell Thimóteo e Lúcia Aguiar assinam a autoria do terceiro artigo desta edição, que discute a prática docente de Ciências e Biologia considerando um questionário aplicado aos estudantes de Ensino Fundamental e Médio cuja temática versava sobre as algas. Rita Josélia da Capela escreve sobre a ciência, seja ela de qual área for, e a busca de um fio condutor para o que, aparentemente, se apresenta como descontínuo, estabelecendo ordenações e relações. O quinto artigo desta edição tem como eixo norteador o filme A Massai Branca e apresenta aspectos culturais, de gênero e a relação com o espaço geográfico e o contexto social em uma perspectiva de trabalho pedagógico que considera a interação entre estudantes e professores de diferentes áreas disciplinares. Tem o filme como ferramenta de aprendizagem e é assinado por Érica Oliveira, Erinaldo Carmo e Fernanda Silva. Encerrando a seção, Christiane Arcuri reflete sobre as artes visuais e a história da arte no CApUERJ, dialogando com / sobre a formação docente.

A discussão sobre a política afirmativa de cotas é o tema do artigo encomendado. Renato Emerson nos brinda com suas reflexões, pesquisa e militância com um texto produzido a partir de sua palestra no VIII Seminário Educação e Sociedade Contemporânea: desafios e propostas, realizado pelo CAp-UERJ em 2013. São importantes reflexões que chegam à e-Mosaicos no mesmo momento em que estamos implantando o sistema de cotas na Educação Básica para o acesso ao Instituto de Aplicação Fernando Rodrigues da Silveira.

Fechamos essa edição com a resenha do livro "A Educação para além do Capital", de István Mézáros. Publicado pela Boitempo Editorial. Carlos Eduardo Filomeno retoma uma obra de grande importância e que permite a renovação de reflexões sobre a educação que queremos para essa e para as próximas gerações dentro da perspectiva de uma educação que saiba lidar com as diferenças e que proporcione uma escola para todos.

Boa leitura! 